\title{
Energy Efficiency Through Lighting and Cooling System Approach
}

\author{
Faaris Mujaahid $^{* 1}$, Doane Puri Mustika ${ }^{1}$, Ramadoni Syahputra ${ }^{1}$, Karisma Trinanda Putra ${ }^{1,2}$, Kunnu
} Purwanto 1

\footnotetext{
${ }^{1}$ Department of Electrical Engineering, Faculty of Engineering, Universitas Muhammadiyah Yogyakarta, Indonesia

${ }^{2}$ Department of Computer Science and Information Engineering, College of Information and Electrical Engineering, Asia University, Taiwan

*Corresponding author, e-mail: f.mujaahid@umy.ac.id
}

\begin{abstract}
This work reports the implementation of using energy efficient electronic devices to reduce the electricity consumption in Universitas Muhammadiyah Yogyakarta (UMY). The first step taken by UMY is to replace lighting and cooling system in all its rooms using energy saving devices. This research was conducted in building E4. This research was conducted by surveying the designated building to get data about lighting and air conditioner devices used in the E4 building. If the proposed concept is applied to lighting and cooling system, UMY would be able to reduce electricity consumption by 29.7 MWh, and this can support the breakthrough of turning UMY into a green campus.
\end{abstract}

Keywords: green campus, efficiency, UMY, energy efficient

\section{Introduction}

Green campus is a system that is run on a campus that requires all citizens to take concrete actions in the form of efficiency and energy conservation to support an environmentally friendly campus and minimize global warming [1]. The main factor that makes electricity as one of the factors causing global warming because electricity production produced in the world is mostly done from the burning of coal [2]. The results of these combustion create several negative effects for the earth that produce carbon dioxide, become air pollutants and even cause global warming. Some things that should be created by the campus to get to the green campus, one of which is to do electricity energy efficiency and electricity energy conservation. Electricity energy efficiency is a real action in the use of low-power electronic devices, while energy conservation is a behavior or action taken by humans in using the device.

But in fact, there are still many campuses that have not done that, one of which is UMY. This research case study is conducted in E4 lecture building. There are still some electronic devices in the building that have not used LED lights, and none have used Air Conditioner (AC) with inverter technology. This study attempts to propose an alternate approach in lighting and cooling systems to understand the concept of green campus and its application at UMY. Besides, this research also encourages campus residents to improve their energy-saving properties and reduce the activities of campus residents who do not care about energy efficiency.

\section{Previous Studies}

Some preliminaries studies discuss about ECI (Energy Consumption Intensity), this is a term to find out the quantity of energy used per unit or activity in a system (building) [3]. The ECI value is known by comparing the total use of electrical energy with the building area. One example is the ECI that was carried out at Psychiatric Hospital Prof Dr HB Saanin in Padang. The collected data were in the form of the building area, the electricity usage, and the budget spent on electricity. From the calculation results, the value of ECI Electricity in 2013 was $155,857 \mathrm{kWh} / \mathrm{m} 2$ per year, the value of ECI in 2014 was $29,291 \mathrm{kWh} / \mathrm{m} 2$ per year, and in 2015 it was $33,216 \mathrm{kWh} / \mathrm{m} 2$ per year. This result is considered good for the efficient category, because the value is far below the ECI electric standard for hospital buildings of $380 \mathrm{kWh} / \mathrm{m} 2$ per year [4].

Copyright $@ 2018$ Universitas Muhammadiyah Yogyakarta - All rights reserved 
Other researchers evaluated the use of LED lamps instead of conventional lamps [5-6]. Production of LED is based on the voltage requirements that are generally used by consumers, namely at a voltage of $220 \mathrm{~V}$. So, the most appropriate LED arrangement is a series of circuits, namely with 25 LEDs. These LEDs will be supplied by a $220 \mathrm{~V}$ voltage that has been rectified so that it matches the needs of the total LED installed. With a rectifier, the output current from the supply is converted to direct current, thus the voltage also periodically reverses. The results indicated better energy efficiency compared to the use of TL lamps.

Some of the research conducted took an example of the case of electricity usage in the environment of the Public Library and Archives of Malang City, in which the electricity consumption is increasing every year. At that time the use of cooling system, $\mathrm{AC}$, has increasingly been used in almost every room. From the calculation results, the library could save the electricity of $19.69 \mathrm{kWh} /$ day or 590.7 $\mathrm{kWh} /$ month. Further savings can be made by minimizing the workings of $\mathrm{AC}$ with temperatures according to the standard and the replacement of conventional $\mathrm{AC}$ that are more than 5 years old by new AC with inverter technology [7].

\section{Method}

This study uses observation and interview methods to those who know the electronic lighting and cooling data in the UMY E4 building, such as UMY Facility \& Asset division, Faculty staff and students in E4 building, and administration staff for the lecture schedules. From this raw data, it is then calculated using some formulas so that it yields the annual electricity bill for the E4 building. Once obtained, the data is recapitulated using Microsoft Excel. Through this application, the calculation of all loads including lightings and $\mathrm{AC}$ can be done. By multiplying the price per $\mathrm{kWh}$, we get the total bill that has to be paid to the electricity provider.

On the other hand, it is necessary to compare the calculation data if the load is replaced using LED lights and AC inverters. The final step is to make an analysis and conclusion through analytical comparisons to determine the cost of electricity tariffs, bill saving and payback periods, as a reference for the university to replace energyefficient lamps and AC.

\section{A. Electric Energy Usage}

Electrical energy consumption is the total load (in
Watt) used in a building from the number of electronic device and multiplied by total time in minutes the electronic device is used. To calculate the use of electrical energy can be calculated in the following way.

$E=\frac{P L \times P C \times t}{1000}$

Where,

$$
\begin{aligned}
& E \text { : electricity consumption (KWh) } \\
& \mathrm{P}_{\mathrm{L}} \text { : Total power of lighting system (Watt) } \\
& \mathrm{P}_{\mathrm{C}} \text { : Total power of cooling system (Watt) } \\
& t \text { : Time consumption (minutes) }
\end{aligned}
$$

\section{B. Electricity Basic Tariff}

Electricity bill is one component of cost analysis that is taken into consideration when determining the type of load. Basic electricity tariffs in Indonesia have been determined in accordance with Presidential Decree No. 104 of 2013 which states that the basic electricity tariff is $\mathrm{Rp} 1.060,00$ for the power subscription of $150 \mathrm{KVA}$.

Bill $=E T \times$ Tariff

Where,

Bill : Total cost of electricity (Rupiah or Rp)

$\mathrm{E}_{\mathrm{T}} \quad$ : Total electricity consumption (KWh)

Tariff : Electricity price per Kwh according to the subscription rate $(\mathrm{Rp} / \mathrm{KWh})$

\section{Time Value of Money}

The time value of money or TVM is a very important concept for an organization that states that the value of money now is more valuable than the value of money in the future. The difference in currency values is due to time differences. It is assumed that the interest rate of $1.02 \%$ is obtained from the average increase in PLN's electricity tariff in the last 5 years. This time value of money can be calculated using the following formula:

$F=P \times(I+i)^{n}$

Where,

$\mathrm{F}$ : Money value in the future (Rupiah or Rp)

$\mathrm{P}$ : Money value at present (Rupiah or $\mathrm{Rp}$ )

I : Interest Rate (constant: 1.02\%)

$\mathrm{n}$ : Number of year after the year of money value at present 


\section{Energy Savings}

Energy efficiency is important to catch more benefits to save electricity bill by focusing on equipment or machines that consume less energy.

$E S=E C-E P$

Where,

ES : Energy saving, a potential saving that can be made after implementing the energy-efficient devices (KWh)

$\mathrm{E}_{\mathrm{C}}$ : Energy consumption from the current devices $(\mathrm{KWh})$

$\mathrm{E}_{\mathrm{P}}$ : Energy consumption after using the energyefficient devices (KWh)

With the implementation of electrical energy efficiency, the obtained bill saving from the results of the electrical energy efficiency is then multiplied by the price of electrical energy per Kwh, see equation (2). The resulting bill saving can be used to replace an existing product with a new product with specifications that are more efficient than before. The payback period from the bill saving results to meet the purchase of new products can be calculated by:

$P P=I C \div B S$

Where:

PP : Payback period, time required to recoup the break-event point (month or year)

IC : Incremental cost or marginal cost, the total money needed with respect to the cash inflow and outflow (Rupiah or Rp)

BS : Bill saving, potential saving that can be made during a certain period (Rupiah or Rp). Result of equation (2)

\section{Result and Discussion}

This study utilizes reference data that already exists at Facility \& Asset division of UMY. The observations are presented in several tables as follows.

TABLE 1

The use of air conditioner at E4 ground floor

\begin{tabular}{clcc}
\hline \hline \multirow{2}{*}{ Room } & AC brand & \multicolumn{2}{c}{ Power } \\
\cline { 3 - 4 } & & HP & Watt \\
\hline E4.001 & Panasonic & 2 & 2090 \\
\hline E4.002 & Samsung & 1.5 & 1120 \\
& Samsung & 1.5 & 1120 \\
\hline E4.003 & Samsung & 1.5 & 1120 \\
\hline
\end{tabular}

\begin{tabular}{llll}
\hline & Samsung & 1.5 & 1120 \\
\hline \multirow{2}{*}{ E4.004 } & Panasonic & 1.5 & 1110 \\
\cline { 2 - 4 } & Panasonic & 1.5 & 1170 \\
\hline \multirow{2}{*}{ E4.006 } & Panasonic & 1.5 & 1170 \\
& Panasonic & 1.5 & 1170 \\
\cline { 2 - 4 } & Panasonic & 1.5 & 1170 \\
\hline
\end{tabular}

TABLE 2

The use of air conditioner at E4 1st floor

\begin{tabular}{llc}
\hline \hline \multicolumn{1}{c}{ Room } & AC Brand & $\begin{array}{c}\text { Power } \\
\text { (Watt) }\end{array}$ \\
\hline Class room 101 & Panasonic & 2090 \\
\hline Seminar room (Dept. of & Panasonic & 1920 \\
\cline { 2 - 3 } International Relation) & Panasonic & 1920 \\
\hline Lab. (Dept. of International & Panasonic & 2090 \\
\cline { 2 - 3 } Relation) & National & 2090 \\
\hline $\begin{array}{l}\text { Administrative office (Dept. } \\
\text { of International Relation) }\end{array}$ & Midea & 1910 \\
\cline { 2 - 3 } Research room & Midea & 1910 \\
\cline { 2 - 3 } & Panasonic & 2090 \\
\cline { 2 - 3 } & Panasonic & 2090 \\
\hline
\end{tabular}

TABLE 3

The use of air conditioner at E4 2nd floor

\begin{tabular}{lll}
\hline \hline \multirow{2}{*}{ Room } & AC Brand & $\begin{array}{c}\text { Power } \\
\text { (Watt) }\end{array}$ \\
\hline SLC room & Panasonic & 2090 \\
\cline { 2 - 3 } & Daikin & 1650 \\
\cline { 2 - 3 } & Daikin & 1650 \\
\hline Lecturer room (Dept. of & Panasonic & 1950 \\
\cline { 2 - 3 } Economics) & Panasonic & 2090 \\
\hline Dept. of Economics office & Daikin & 1650 \\
\hline Stock Exchange practical & Panasonic & 2040 \\
\cline { 2 - 3 } room & Panasonic & 2040 \\
\cline { 2 - 3 } & Sharp & 1290 \\
\hline Administrative office & Panasonic & 840 \\
\hline Accounting lab & Panasonic & 1750 \\
\cline { 2 - 3 } & Panasonic & 1950 \\
\hline Lab & Ucida & 1700 \\
\cline { 2 - 3 } & Samsung & 800 \\
\cline { 2 - 3 } & Panasonic & 840 \\
\cline { 2 - 3 } & Panasonic & 840 \\
\hline
\end{tabular}

TABLE 4

The use of lamp at E4 ground floor

\begin{tabular}{llc}
\hline \hline \multicolumn{1}{c}{ Room } & \multicolumn{1}{c}{ Type } & $\begin{array}{c}\text { Power } \\
\text { (Watt) }\end{array}$ \\
\hline $\mathbf{E 4 . 0 0 1}$ & TL LED & 96 \\
\hline $\mathbf{E 4 . 0 0 2}$ & TL LED & 96 \\
\hline $\mathbf{E 4 . 0 0 3}$ & TL LED & 96 \\
\hline $\mathbf{E 4 . 0 0 4}$ & TL LED & 96 \\
\hline $\mathbf{E 4 . 0 0 5}$ & TL LED & 96 \\
\hline E4.006 & TL LED & 64 \\
\hline Rest room & TL Ring & 88 \\
\cline { 2 - 3 } (woman) & TL Fluerescent & 36 \\
\hline Rest room & TL Ring & 88 \\
(man) & TL Fluerescent & 36 \\
\hline Corridor & TL Ring & 44 \\
\cline { 2 - 3 } & LED BULB & 36 \\
\hline
\end{tabular}


TABLE 5

The use of lamp at E4 1st floor

\begin{tabular}{llc}
\hline \multicolumn{1}{c}{ Room } & \multicolumn{1}{c}{ Type } & $\begin{array}{c}\text { Power } \\
\text { (Watt) }\end{array}$ \\
\hline Class room 101 & TL LED & 96 \\
\hline $\begin{array}{l}\text { Seminar room (Dept. } \\
\text { of International } \\
\text { Relation) }\end{array}$ & TL LED & 96 \\
\hline $\begin{array}{l}\text { Lab. (Dept. of } \\
\text { International Relation) }\end{array}$ & TL LED & 96 \\
\hline $\begin{array}{l}\text { Administrative office } \\
\text { (Dept. of International } \\
\text { Relation) }\end{array}$ & TL LED & 64 \\
\hline Research room & TL LED & 64 \\
\hline Rest room (woman) & TL Ring & 88 \\
\cline { 2 - 3 } & TL Fluorescent & 36 \\
\hline Rest room (man) & TL Ring & 88 \\
\cline { 2 - 3 } & TL Fluorescent & 36 \\
\hline Corridor & TL Ring & 22 \\
\cline { 2 - 3 } & LED Bulb & 60 \\
\hline Stairs & TL.Ring & 88 \\
\hline
\end{tabular}

TABLE 6

The use of lamp at E4 2nd floor

\begin{tabular}{llc}
\hline \hline \multicolumn{1}{c}{ Room } & \multicolumn{1}{c}{ Type } & $\begin{array}{c}\text { Power } \\
\text { (Watt) }\end{array}$ \\
\hline SLC room & LED BULB & 108 \\
\cline { 2 - 3 } & LED BULB & 24 \\
\hline $\begin{array}{l}\text { Lecturer room (Dept. of } \\
\text { Economics) }\end{array}$ & TL LED & 160 \\
\hline $\begin{array}{l}\text { Dept. of Economics } \\
\text { office }\end{array}$ & TL LED & 64 \\
\hline $\begin{array}{l}\text { Stock Exchange } \\
\text { practical room }\end{array}$ & TL LED & 160 \\
\hline Administrative office & TL LED & 64 \\
\hline Accounting lab & TL LED & 160 \\
\hline Lab & TL Ring & 72 \\
\hline Rest room (woman) & TL Ring & 88 \\
\cline { 2 - 3 } & TL Fluorescent & 36 \\
\hline Rest room (man) & TL Ring & 88 \\
\cline { 2 - 3 } & TL Fluorescent & 36 \\
\hline Corridor & TL Ring & 44 \\
\hline & LED BULB & 36 \\
\hline Stairs & TL.Ring & 88 \\
\hline
\end{tabular}

TABLE 7

The use of room every week

\begin{tabular}{lc}
\hline \hline \multicolumn{1}{c}{ Room } & $\begin{array}{c}\text { Time } \\
\text { (hour/ week) }\end{array}$ \\
\hline $\mathbf{E 4 . 0 0 1}$ & 50.67 \\
\hline $\mathbf{E 4 . 0 0 2}$ & 50.67 \\
\hline $\mathbf{E 4 . 0 0 3}$ & 50.67 \\
\hline $\mathbf{E 4 . 0 0 4}$ & 50.67 \\
\hline $\mathbf{E 4 . 0 0 5}$ & 52.17 \\
\hline $\mathbf{E 4 . 0 0 6}$ & 50.67 \\
\hline Class room 101 & 50.67 \\
\hline Seminar room (Dept. of International & 50.67 \\
\hline
\end{tabular}

\begin{tabular}{ll}
\hline Relation) & \\
\hline Lab. (Dept. of International Relation) & 44 \\
\hline $\begin{array}{l}\text { Administrative office (Dept. of } \\
\text { International Relation) }\end{array}$ & 44 \\
\hline Research room & 44 \\
\hline SLC room & 44 \\
\hline Lecturer room (Dept. of Economics) & 44 \\
\hline Dept. of Economics office & 44 \\
\hline Stock Exchange practical room & 44 \\
\hline Administrative office & 44 \\
\hline Accounting lab & 47 \\
\hline Lab & 46 \\
\hline Rest room & 84 \\
\hline Corridor & 84 \\
\hline Stairs & 28 \\
\hline
\end{tabular}

Each floor in the E4 building has different amount of energy from lighting and cooling system. See table 8 below for the total energy consumption per room in every floor, lamp and AC are written in separate column.

TABLE 8

Energy consumption at E4 per week

\begin{tabular}{|c|c|c|c|c|}
\hline \multirow{2}{*}{ Room } & \multicolumn{2}{|c|}{ Power } & \multirow{2}{*}{$\begin{array}{l}\text { Time } \\
\text { (hour) }\end{array}$} & \multirow{2}{*}{$\begin{array}{l}\text { Energy } \\
\text { (KWh) }\end{array}$} \\
\hline & Lamp & AC & & \\
\hline E4.001 (GF) & 96 & 2090 & 50.67 & 110.8 \\
\hline E4.002 (GF) & 96 & 2240 & 50.67 & 118.4 \\
\hline E4.003 (GF) & 96 & 2240 & 50.67 & 118.4 \\
\hline E4.004 (GF) & 96 & 2280 & 50.67 & 120.4 \\
\hline E4.005 (GF) & 96 & 1170 & 52.17 & 66 \\
\hline E4.006 (GF) & 64 & 2340 & 50.67 & 121.8 \\
\hline $\begin{array}{l}\text { Rest room } \\
\text { (woman) (GF) }\end{array}$ & 124 & & 84 & 10.4 \\
\hline $\begin{array}{l}\text { Rest room } \\
(\operatorname{man})(\mathbf{G F})\end{array}$ & 124 & & 84 & 10.4 \\
\hline Corridor (GF) & 80 & & 84 & 6.7 \\
\hline Class room $101(1 \mathrm{~F})$ & 96 & 2090 & 50.67 & 110.8 \\
\hline $\begin{array}{l}\text { Seminar room } \\
\text { (Dept. of } \\
\text { International } \\
\text { Relation) (1F) }\end{array}$ & 96 & 3840 & 50.67 & 199.4 \\
\hline $\begin{array}{l}\text { Lab. (Dept. of } \\
\text { International } \\
\text { Relation) (1F) }\end{array}$ & 96 & 4180 & 44 & 188.1 \\
\hline $\begin{array}{l}\text { Administrative } \\
\text { office (Dept. of } \\
\text { International } \\
\text { Relation) (1F) }\end{array}$ & 64 & 3820 & 44 & 170.9 \\
\hline Research room (1F) & 64 & 2090 & 44 & 94.8 \\
\hline $\begin{array}{l}\text { Rest room } \\
\text { (woman) (1F) }\end{array}$ & & 124 & 84 & 10.4 \\
\hline $\begin{array}{l}\text { Rest room } \\
(\operatorname{man})(1 \mathrm{~F})\end{array}$ & & 124 & 84 & 10.4 \\
\hline Corridor (1F) & & 82 & 84 & 6.9 \\
\hline Stairs (1F) & & 88 & 28 & 2.5 \\
\hline SLC room (2F) & 132 & 5390 & 44 & 3 \\
\hline $\begin{array}{l}\text { Lecturer room } \\
\text { (Dept. of }\end{array}$ & 160 & 4040 & 44 & 184.8 \\
\hline
\end{tabular}




\begin{tabular}{|c|c|c|c|c|}
\hline \multicolumn{5}{|l|}{ Economics) $(2 \mathrm{~F})$} \\
\hline $\begin{array}{l}\text { Dept. of Economics } \\
\text { office }(2 \mathrm{~F})\end{array}$ & 64 & 1650 & 44 & 75.4 \\
\hline $\begin{array}{l}\text { Stock Exchange } \\
\text { practical room (2F) }\end{array}$ & 160 & 5370 & 44 & 243.3 \\
\hline $\begin{array}{l}\text { Administrative } \\
\text { office }(2 F)\end{array}$ & 64 & 840 & 44 & 39.8 \\
\hline Accounting lab (2F) & 160 & 3700 & 47 & 181.4 \\
\hline Lab (2F) & 72 & 4180 & 46 & 195.6 \\
\hline $\begin{array}{l}\text { Rest room } \\
\text { (woman) (2F) }\end{array}$ & 124 & & 84 & 10.4 \\
\hline $\begin{array}{l}\text { Rest room } \\
(\text { man })(2 F)\end{array}$ & 124 & & 84 & 10.4 \\
\hline Corridor (2F) & 80 & & 84 & 6.7 \\
\hline Stairs (2F) & 88 & & 28 & 2.5 \\
\hline Total energy & nsum & on/ we & & 2670.8 \\
\hline
\end{tabular}

Thus, to find out the amount of electrical energy used in the E4 building of UMY, it can be calculated using equation (1). From table 8, PL and $\mathrm{PC}$ refer to Lamp and AC respectively, $\mathrm{t}$ is the time (in hour). Then, the total electricity consumption in one year for lamps and $\mathrm{AC}$ in the $\mathrm{E} 4$ building is the total energy consumption in a week $(2.67 \mathrm{MWh})$ multiplied by $52 \frac{1}{7}$, equals to $139.3 \mathrm{MWh} .52 \frac{1}{7}$ is the total week in a year; 52 weeks and 1 day ( $\frac{1}{7}$ week).

If all the non-LED lightings are replaced by LED and all the old ACs are replaced by the inverter-AC, there is huge electricity saving that can be made. Using equation (2) and (4), a potential reduction of $28.1 \mathrm{MWh} /$ year can be reached. If the electricity tariff is $1040 \mathrm{rupiah} / \mathrm{KWh}$, then the saving will be about 29.2 million rupiah/ year.

\section{Conclusion}

Based on the results and comparative analysis between the use of conventional devices and energy saving devices, it can be concluded that:

1. From the results of the analysis conducted, the cooling and lighting system in the E4 building still use conventional AC (all) and TL lamps (partially). This resulted in higher electricity energy consumption in the building.

2. Through calculations, the electrical energy used by UMY for cooling and lighting in E4 building every year is $139.3 \mathrm{MWh}$.

3. If you make a switch to $\mathrm{AC}$ with inverter technology and LED lights, the energy savings in the UMY E4 building is $28.1 \mathrm{MWh}$ annually and has the potential to save costs as much as 29.2 million rupiah.

\section{References}

[1] Asnal Effendi dan Ahsanul. 2013. "Analisis Audit Energi Untuk Pencapaian Efisisensi Energi Di Gedung AB Kabupaten Tangerang" https://publikasi.mercubuana.ac.id.

[2] Firdaus Pratama,dkk. 2014, "Analisis Audit Energi Untuk Pencapaian Efisisensi Energi Listrik PT. Intan Pariwara Klaten" https://dspace.uii.ac.id.

[3] Jati Untoro, dkk. 2014, "Audit Energi dan Analisis Penghematan Konsumsi Energi pada Sistem Peralatan Listrik di Gedung Pelayanan Unila" https://electrician.unila.ac.id.

[4] Jawoto Tri, dkk. 2017. "Audit Energi Listrik Untuk Meningkatkan Efisisensi di Gedung FISIP Universitas Brawijaya”. https://elektro.studentjournal.ub.ac.id.

[5] Surihajanto dkk. 2013. "Melakukan Evaluasi Penggunaan Lampu LED Sebagai Lampu Konvensional " http:// journal.unisla.ac.id.

[6] Jimmy, dkk. 2013. "Analisa Penggunaan Lampu LED Pada Penerangan Dalam Rumah" https://ejournal.undip.ac.id.

[7] Yoga Prasetya, 2014, ”Analisis Peningkatan Pada Keefisienan Penggunaan Energi Listik Pada Sistem Pencahayaan dan AC Di Gedung Perpustakaan Umum dan Arsip Daerah Kota Malang" https://elektro.studentjournal.ub.ac.id.

[8] Joko Prihartono, dkk. 2016. "Audit Energi dan Analisis Peluang Penghematan Energi Listrik Gedung Mahkamah Konstitusi Jakarta" https://ejournal.upp.ac.id.

[9] Rahmat Adiprasetya. 2015. "Analisis Dampak Konsevasi Energi Pada Permintaan dan Penyediaan Energi Listrik di Jawa Timur", https://repository.umy.ac.id.

[10] Yadi Mulyadi, dkk. 2013. "Analisis Audit Energi Untuk Pencapaian Efisiensi Penggunaan Energi di Gedung FPMIPA JICA Universitas Pendidikan Indonesia”. http://ejournal.upi.edu.

\section{Authors' information}

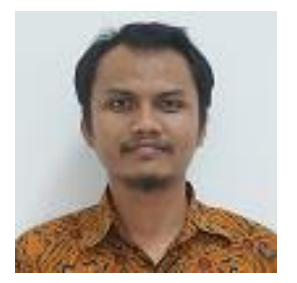

Faaris Mujaahid Hold a bachelor degree in 2010 from Electrical and Electronics Engineering Department, Saxion University of Applied Sciences, the Netherlands. He received a master degree in Sustainable Energy Technologies in 2016 from University of Southampton, UK. ing. Faaris Mujaahid, M.Sc is currently a lecturer in the Department of Electrical Engineering, Faculty of Engineering, Universitas Muhammadiyah Yogyakarta, Indonesia. His main research interest is in LabVIEW and renewable energy (mainly in solar cell material and fabrication technologies). 
Doane Puri Mustika is a bachelor student of Electrical Engineering, Faculty of Engineering, Universitas Muhammadiyah Yogyakarta, expected to finish his study in 2019.

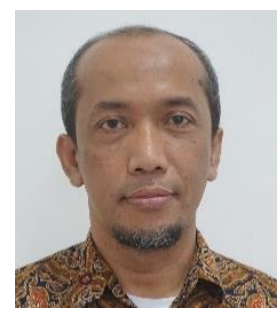

Ramadoni Syahputra received B.Sc. degree from Institut Teknologi Medan in 1998, M.Eng. degree from Department of Electrical Engineering, Universitas Gadjah Mada, Yogyakarta, Indonesia in 2002, and Ph.D degree at the Department of Electrical Engineering, Faculty of Industrial Technology, Institut Teknologi Sepuluh Nopember, Surabaya, Indonesia in 2015. Dr. Ramadoni Syahputra is a Lecturer in Department of Electrical Engineering, Faculty of Engineering, Universitas Muhammadiyah Yogyakarta, Indonesia. His research interests are in computational of power system, artificial intelligence in power system, power system control, the application of fuzzy logic in power system, optimization, distributed energy resources, and renewable energy.

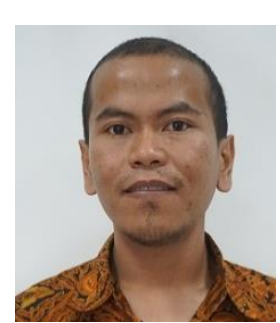

Karisma T. Putra born in Bondowoso on June 19, 1990. Graduated from elementary to senior high school in Bondowoso until 2008. Studied bachelor degree program in Surabaya, precisely in Electronics Engineering Polytechnic Institute of Surabaya (EEPIS) until 2012. He got scholarship program to continue master degree in Institut Teknologi Sepuluh Nopember (ITS) Surabaya. Now, he is doing a doctorate degree in Asia University Taiwan. Karisma is also a lecturer at Electrical Engineering, Faculty of Engineering, Universitas Muhammadiyah Yogyakarta. The main focus of research is the intelligent systems and controls. He engaged in joint research related to the development of food commodity tracking systems and integrated intelligent systems. He was involved in several competitions in developing smart devices. Pursue the field of electronics and software development since college. Mr. Putra joined in Indonesian's engineer union organization (PII) in 2016. Mr. Putra is also active in writing publications on IEEE society.

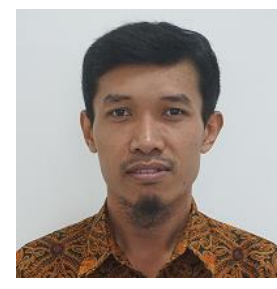

Kunnu Purwanto is a lecturer and researcher in Electrical Engineering Department, Faculty of Engineering, Universitas Muhammadiyah Yogyakarta (UMY). He received bachelor degree from UMY and M.Eng degree from Universitas Gadjah Mada (UGM). Kunnu Purwanto is actively involved in national robotic contest and activities as a delegate from UMY. 